\title{
A significant carbon sink in temperate forests in Beijing: based on 20-year field measurements in three stands
}

\author{
ZHU JianXiao $^{1 \dagger}$, HU XueYang ${ }^{1 \dagger}$, YAO Hui ${ }^{1}$, LIU GuoHua ${ }^{2}$, JI ChenJun $^{1} \&$ FANG JingYun ${ }^{1 *}$ \\ ${ }^{1}$ Department of Ecology, College of Urban and Environmental Science, and Key Laboratory for Earth Surface Processes of the Ministry of \\ Education, Peking University, Beijing 100871, China; \\ ${ }^{2}$ Research Center for Eco-Environmental Sciences, Chinese Academy of Sciences, Beijing 100085, China
}

Received July 9, 2015; accepted August 24, 2015; published online October 23, 2015

\begin{abstract}
Numerous efforts have been made to characterize forest carbon (C) cycles and stocks in various ecosystems. However, long-term observation on each component of the forest $\mathrm{C}$ cycle is still lacking. We measured $\mathrm{C}$ stocks and fluxes in three permanent temperate forest plots (birch, oak and pine forest) during 2011-2014, and calculated the changes of the components of the C cycle related to the measurements during 1992-1994 at Mt. Dongling, Beijing, China. Forest net primary production in birch, oak, and pine plots was $5.32,4.53$, and $6.73 \mathrm{Mg} \mathrm{C} \mathrm{ha}^{-1} \mathrm{a}^{-1}$, respectively. Corresponding net ecosystem production was $0.12,0.43$, and $3.53 \mathrm{Mg} \mathrm{Cha}^{-1} \mathrm{a}^{-1}$. The $\mathrm{C}$ stocks and fluxes in 2011-2014 were significantly larger than those in 1992-1994 in which the biomass $\mathrm{C}$ densities in birch, oak, and pine plots increased from 50.0, 37.7, and 54.0 $\mathrm{Mg} \mathrm{C}^{-1}$ in 1994 to 101.5 , 77.3, and 110.9 $\mathrm{Mg} \mathrm{C} \mathrm{ha}^{-1}$ in 2014; soil organic $\mathrm{C}$ densities increased from 207.0, 239.1, and 231.7 $\mathrm{Mg} \mathrm{C}^{-1}$ to 214.8, 241.7, and $238.4 \mathrm{Mg} \mathrm{C} \mathrm{ha}^{-1}$; and soil heterotrophic respiration increased from $2.78,3.49$, and $1.81 \mathrm{Mg} \mathrm{C}^{-1} \mathrm{a}^{-1}$ to $5.20,4.10$, and $3.20 \mathrm{Mg} \mathrm{Cha}^{-1} \mathrm{a}^{-1}$. These results suggest that the mountainous temperate forest ecosystems in Beijing have served as a carbon sink in the last two decades. These observations of $\mathrm{C}$ stocks and fluxes provided field-based data for a long-term study of $\mathrm{C}$ cycling in temperate forest ecosystems.
\end{abstract}

carbon density, carbon flux, carbon cycle, carbon budget, permanent plot, temperate forest

Citation: Zhu JX, Hu XY, Yao H, Liu GH, Ji CJ, Fang JY. A significant carbon sink in temperate forests in Beijing: based on 20-year field measurements in three stands. Sci China Life Sci, 2015, 58: 1135-1141, doi: 10.1007/s11427-015-4935-Z

Temperate forests in the Northern Hemisphere function as an important sink for atmospheric carbon dioxide $\left(\mathrm{CO}_{2}\right)$ [1-5]; however, their magnitude and changes continue to include large uncertainties [6-10]. Long-term ecosystem-scale estimation of $\mathrm{C}$ budgets can help reduce these uncertainties. Although a considerable number of studies have focused on one or more major components of the forest ecosystem $\mathrm{C}$ cycle [11-13], comprehensive measurements involving $\mathrm{C}$ cycling of entire forest sectors have seldom been documented [14]. The evaluations of long-term changes of $\mathrm{C}$

$\dagger$ Contributed equally to this work

*Corresponding author (email: jyfang@urban.pku.edu.cn) cycling processes are even more rarely reported $[15,16]$.

Net ecosystem production (NEP) serves as a measure of the net $\mathrm{C}$ accumulation by forests and other ecosystems. Researchers have generally used three approaches to estimating NEP in forests: (i) the aggregated-flux method uses measurements of growth, mortality, litterfall, decomposition, soil respiration $\left(R_{\mathrm{s}}\right)$ and heterotrophic respiration $\left(R_{\mathrm{h}}\right)$ to calculate short-term NEP of an ecosystem [17]; (ii) the delta-stores method uses measurements of the changes in total C stocks, including biomass, soil, litter and woody debris to estimate long-term NEP in a permanent forest stand [18]; and (iii) the micrometerologic method, e.g. an eddy covariance method, is used to determine $\mathrm{CO}_{2}$ fluxes 
inside a forest [19]. The eddy covariance method is commonly applicable for areas with smooth terrain, but has not been widely used in mountainous forests [20]. Here, we used aggregated-flux and delta-stores methods to estimate 20-year changes in net primary production (NPP), $R_{\mathrm{s}}, R_{\mathrm{h}}$, and total $\mathrm{C}$ stocks of three mountainous temperate forests at Mt. Dongling, Beijing.

Fang et al. [17] established three temperate forest stands (birch forest, Betula platyphylla; oak forest, Quercus wutaishanica; and pine plantation, Pinus tabuliformis) in Mt. Dongling during 1992-1994. They found that pine forest accumulated $\mathrm{C}$, while birch and oak forests were nearly in balance in $\mathrm{CO}_{2}$ exchange between the atmosphere and these two ecosystems. In this study, during 2011-2014, we re-investigated the same three permanent temperate forest plots, using protocols that were used in the previous study [17], to measure forest $\mathrm{C}$ stocks and fluxes. The objectives of the present study are to quantify the major components of $\mathrm{C}$ cycling and to evaluate the changes in the process of $\mathrm{C}$ cycling of these three forest ecosystems during the last two decades.

\section{Materials and methods}

\subsection{Site description}

The study site on Mt. Dongling stands near the Xiaolongmen forestland. The temperate forests in this region are protected and have not experienced serious anthropogenic disturbance [21]. The three permanent forest stands, including deciduous broadleaf birch and oak forests, and a pine plantation, were established in 1992 [17,22]. We reinvestigated these three plots in July 2011. Table 1 provides detailed information on these study sites and additional information is available in Fang et al. [17] and Yao et al. [23].

\subsection{Measurements of $\mathrm{C}$ density and flux}

The $\mathrm{C}$ densities of biomass, litter, woody debris, and soil organic matter were measured in July 2011 and July 2014. The measurement protocol of each component was completely consistent with those in 1992-1994 [17].

\subsubsection{Biomass and net biomass increment}

We measured height $(H)$ and diameter at breast height (DBH) for each stem of trees with $\mathrm{DBH}>3 \mathrm{~cm}$ in each plot in July 2011. We calculated biomass of each tree by allometric equations (Table S1). Only DBH was measured in 2014, and thus $H$ was estimated using eqs. (1-3) based on the relationships between girth $(G, \pi \mathrm{DBH})$ and $H$ that were developed based on 2011 data:

$$
\begin{gathered}
\text { Birch forest: } H=0.4818 G^{0.8319}\left(R^{2}=0.78, n=131\right), \\
\text { Oak forest: } H=0.9358 G^{0.5810}\left(R^{2}=0.79, n=168\right), \\
\text { Pine plantation: } H=0.6175 G^{0.7357}\left(R^{2}=0.82, n=123\right) .
\end{gathered}
$$

Three $10 \times 10 \mathrm{~m}^{2}$ subplots were established in each plot and used to measure biomass of understory shrubs and seedlings $(\mathrm{DBH}<3 \mathrm{~cm})$. We measured base diameter and height of all woody plants, including tree seedlings, in July 2011. Allometric equations (Table S2) were used to calculate the biomass of understory shrubs and seedlings. Five $1 \times 1 \mathrm{~m}^{2}$ subplots were established to measure the biomass of the herb layer (harvested and weighted).

Based on tree biomass in 2011 and 2014, we estimated the net biomass increment for each plot. We assumed that the biomasses of understory and herb layers in 2014 were the same as those in 2011. A standard factor of 0.5 was used to convert biomass to $\mathrm{C}$ in this study [24].

\subsubsection{Litter and woody debris}

We installed 10 litter traps $\left(1 \times 1 \mathrm{~m}^{2}\right)$ at each plot in July 2011. Litter was collected monthly during the growing sea-

\begin{tabular}{|c|c|c|c|c|}
\hline Item & Period & Birch & Oak & Pine \\
\hline Latitude & & $39^{\circ} 57^{\prime} 06^{\prime \prime} \mathrm{N}$ & $39^{\circ} 57^{\prime} 26^{\prime \prime} \mathrm{N}$ & $39^{\circ} 57^{\prime} 34^{\prime \prime} \mathrm{N}$ \\
\hline Longitude & & $115^{\circ} 25^{\prime} 39^{\prime \prime} \mathrm{E}$ & $115^{\circ} 25^{\prime} 29^{\prime \prime} \mathrm{E}$ & $115^{\circ} 25^{\prime} 40^{\prime \prime} \mathrm{E}$ \\
\hline Elevation (m) & & 1350 & 1150 & 1050 \\
\hline Area $\left(m^{2}\right)$ & & $30 \times 40$ & $30 \times 40$ & $20 \times 50$ \\
\hline Aspect & & NW & SW & SE \\
\hline Slope $\left(^{\circ}\right)$ & & 28 & 33 & 30 \\
\hline \multirow{2}{*}{$\begin{array}{l}\text { Individuals per plot } \\
\qquad\left(\text { stem ha }^{-1}\right)\end{array}$} & 1992-1994 & 1618 & 1394 & 1963 \\
\hline & 2011-2014 & 1456 & 1853 & 1886 \\
\hline \multirow{2}{*}{ Mean DBH $(\mathrm{cm})$} & 1992-1994 & 10.3 & 10.1 & 12.6 \\
\hline & 2011-2014 & 13.8 & 11.0 & 16.6 \\
\hline \multirow{2}{*}{ Mean height (m) } & 1992-1994 & 9.0 & 6.6 & 9.1 \\
\hline & 2011-2014 & 11.0 & 6.9 & 11.6 \\
\hline
\end{tabular}
son (April to November) from August 2011 until July 2014.

Table 1 Characteristics of study sites for three temperate forests, birch, oak, and pine, in the two study periods 
After collection, litter was taken to the laboratory, oven dried at $65^{\circ} \mathrm{C}$ to a constant weight, weighed, and then annual litter production $\left(\mathrm{Mg} \mathrm{C} \mathrm{ha} \mathrm{a}^{-1}\right)$ was calculated. We estimated dead root production ( $\mathrm{Mg} \mathrm{C} \mathrm{ha} \mathrm{ha}^{-1}$ ) using eq. (4) $[14,25]$ :

$$
\text { Root production }=\frac{\text { Litter production }}{\text { Aboveground biomass }} \times \text { Root biomass } .
$$

Woody debris production represents the losses from the mortality (that is, death of entire trees) per year. In addition, we measured the stocks of litter and woody debris by harvest and weight in July 2011. Sub-samples of litter and woody debris were air dried for 2 weeks at $25^{\circ} \mathrm{C}$, and then ground and sieved $(0.15 \mathrm{~mm})$. The $\mathrm{C}$ concentrations of both litter and woody debris were determined using an Elemental Analyzer (2400 II CHN Elemental Analyzer; Perkin-Elmer, Boston, USA).

\subsubsection{Soil}

We also sampled three replicated soil profiles for each plot to estimate soil $\mathrm{C}$ density. Bulk density of each depth was estimated using a standard container $\left(100 \mathrm{~cm}^{3}\right)$. Soil samples were pulverized for measurement of soil organic matter concentration by wet combustion with $\mathrm{K}_{2} \mathrm{Cr}_{2} \mathrm{O}_{7}$ [26]. Fang et al. [17] provide details on the methodology.

\subsection{Measurements of soil respiration}

For each plot, we inserted 10 polyvinyl chloride collars (20 $\mathrm{cm}$ inside diameter) into the soil to allow the measurement of the soil respiration $\left(R_{\mathrm{S}}\right) ; R_{\mathrm{s}}$ was measured from May 2012 until May 2015 using an Li-8100 Automated Soil $\mathrm{CO}_{2}$ Flux System (Li-Cor Inc., Lincoln, USA). The apparent dependence of $R_{\mathrm{s}}$ on temperature ( $5 \mathrm{~cm}$ depth) was calculated using eq. (5):

$$
R_{\mathrm{s}}=a \times \mathrm{e}^{b T},
$$

where $T$ is the examined soil temperature at $5 \mathrm{~cm}$ below surface, $a$ and $b$ are the regression coefficients, and the unit of $R_{\mathrm{s}}$ is $\mu \mathrm{mol} \mathrm{CO}_{2} \mathrm{~m}^{-2} \mathrm{~s}^{-1}$.

Continuous soil temperature at $5 \mathrm{~cm}$ below surface soil in each plot was monitored hourly by a StowAway TidbiT data logger (Onset Computer Corporation, Bourne, USA). Based on the relationship between $R_{\mathrm{s}}$ and the daily $T$ (eq. (5)), we estimated the annual soil efflux $\left(\mathrm{Mg} \mathrm{C} \mathrm{ha}{ }^{-1}\right.$ $\left.\mathrm{a}^{-1}\right)$ [23]. We used the ratio of heterotrophic respiration $\left(R_{\mathrm{h}}\right)$ to $R_{\mathrm{S}}$ in 1994 and 1995 to estimate the $R_{\mathrm{h}}$ during 2011-2014 [22].

\subsection{Production calculation}

We modified the calculation of net primary production (NPP, Mg C ha-1 $\mathrm{a}^{-1}$ ) in 1992-1994 to create eq. (6) [17]:

$$
\mathrm{NPP}=L+F+W+\Delta B,
$$

where $L$ and $\Delta B$ were litter production and net biomass increment, respectively; and $F$ and $W$ were dead root production and woody debris production, respectively. The units of $L, \Delta B, F$, and $W$ were $\mathrm{Mg} \mathrm{Cha} \mathrm{ha}^{-1}$.

The net ecosystem production (NEP) was calculated by NPP minus $R_{\mathrm{h}}$ :

$$
\mathrm{NEP}=\mathrm{NPP}-R_{\mathrm{h}}
$$

\section{Results}

\subsection{C stocks and changes in two decades}

During 2011-2014, biomass C stocks in birch, oak, and pine forests were 93.1-101.6, 72.1-77.5, and 100.3-111.2 Mg C $\mathrm{ha}^{-1}$, respectively. Tree biomass accounted for more than 97\% of total biomass $\mathrm{C}$ pools, compared with the understory and herb layer $(<3 \%)$ contributing a relatively lower amount. The corresponding stocks of the three forests in soil organic matter, litter, and woody debris $\mathrm{C}$ stocks were 214.8, 241.7, and 238.4 $\mathrm{Mg} \mathrm{Cha}^{-1}, 11.4,6.1$, and 2.1 Mg C $\mathrm{ha}^{-1}$, and 5.6, 3.3, and 4.5 $\mathrm{Mg} \mathrm{C} \mathrm{ha}^{-1}$, respectively. Compared with the data in 1992-1994, biomass C stocks in the three forests increased by $51.5,39.6$, and $56.9 \mathrm{Mg} \mathrm{C} \mathrm{ha}^{-1}$, respectively; soil organic $\mathrm{C}$ stocks increased by 7.8, 2.6, and 6.7 $\mathrm{Mg} \mathrm{C} \mathrm{ha}{ }^{-1}$. Compared with the contribution of biomass, the contribution of soil organic $\mathrm{C}$ stocks decreased in the last two decades. In short, almost all of the components of the forest $\mathrm{C}$ sectors (except for litter in pine forest) increased in the last two decades (Table 2).

\subsection{C fluxes and changes in two decades}

The net biomass increment $(\Delta B)$ in birch, oak, and pine forests were $2.83,1.79$, and $3.65 \mathrm{Mg} \mathrm{C} \mathrm{ha}^{-1} \mathrm{a}^{-1}$ during 2011-2014, respectively. The corresponding productions in litter, dead root, and woody debris of these three forests were $1.84,2.02$, and $2.45 \mathrm{MgCha} \mathrm{Ca}^{-1} ; 0.46,0.65$, and $0.57 \mathrm{Mg} \mathrm{C} \mathrm{ha}^{-1} \mathrm{a}^{-1} ; 0.19,0.07$, and $0.06 \mathrm{Mg} \mathrm{Cha}^{-1} \mathrm{a}^{-1}$, respectively. Annual soil respiration $\left(R_{\mathrm{s}}\right)$ and heterotrophic respiration $\left(R_{\mathrm{h}}\right)$ effluxes in birch, oak, and pine forests were 5.74, 4.55, and 4.14 $\mathrm{Mg} \mathrm{C} \mathrm{ha}^{-1} \mathrm{a}^{-1} ; 5.20,4.10$, and 3.20 Mg $\mathrm{C} \mathrm{ha} \mathrm{a}^{-1} \mathrm{a}^{-1}$, respectively. Accordingly, NPP of birch, oak and pine forests was estimated as 5.32, 4.53 and $6.73 \mathrm{Mg} \mathrm{C} \mathrm{ha}^{-1}$ $\mathrm{a}^{-1}$, respectively; and NEP was $0.12,0.43$, and $3.53 \mathrm{Mg} \mathrm{C}$ $\mathrm{ha}^{-1} \mathrm{a}^{-1}$. Compared with the estimates in 1992-1994, $\Delta B$ in these three forests increased by 0.73 (35\%), 0.46 (35\%), and $0.10(3 \%) \mathrm{Mg} \mathrm{C} \mathrm{ha}^{-1} \mathrm{a}^{-1}$, respectively. As the major components of NPP, including productions of litter, dead root, and woody debris, increased in the last two decades. For example, compared with the values in 1992-1994, litter production in the three forests increased by 0.21 (13\%), $0.19(8 \%)$, and $0.09(5 \%) \mathrm{Mg} \mathrm{C} \mathrm{ha}^{-1} \mathrm{a}^{-1}$, respectively, during 2011-2014. NPP in these three forests increased by 1.09 
Table 2 Carbon stocks $\left(\mathrm{Mg} \mathrm{Cha}{ }^{-1}\right)$ and fluxes $\left(\mathrm{Mg} \mathrm{C} \mathrm{ha}^{-1} \mathrm{a}^{-1}\right)$ during two study periods for three forest types, birch, oak, and pine

\begin{tabular}{|c|c|c|c|c|c|c|c|c|c|c|c|c|}
\hline \multirow{3}{*}{ Item } & \multicolumn{4}{|c|}{ Birch } & \multicolumn{4}{|c|}{ Oak } & \multicolumn{4}{|c|}{ Pine } \\
\hline & \multicolumn{2}{|c|}{ 1992-1994 } & \multicolumn{2}{|c|}{ 2011-2014 } & \multicolumn{2}{|c|}{ 1992-1994 } & \multicolumn{2}{|c|}{ 2011-2014 } & \multicolumn{2}{|c|}{ 1992-1994 } & \multicolumn{2}{|c|}{ 2011-2014 } \\
\hline & 1992 & 1994 & 2011 & 2014 & 1992 & 1994 & 2011 & 2014 & 1992 & 1994 & 2011 & 2014 \\
\hline \multicolumn{13}{|l|}{ Stock $\left(\mathrm{Mg} \mathrm{C} \mathrm{ha}{ }^{-1}\right)$} \\
\hline Tree biomass & 45.7 & 49.9 & 90.3 & 98.8 & 35.0 & 37.7 & 71.3 & 76.7 & 47.0 & 54.0 & 99.9 & 110.8 \\
\hline Shrub biomass & \multicolumn{2}{|c|}{0.1} & \multicolumn{2}{|c|}{2.7} & \multicolumn{2}{|c|}{0.0} & \multicolumn{2}{|c|}{0.6} & \multicolumn{2}{|c|}{0.0} & \multicolumn{2}{|c|}{0.1} \\
\hline Herb biomass & \multicolumn{2}{|c|}{ N.D. } & \multicolumn{2}{|c|}{0.1} & \multicolumn{2}{|c|}{ N.D. } & \multicolumn{2}{|c|}{0.2} & \multicolumn{2}{|c|}{ N.D. } & \multicolumn{2}{|c|}{0.3} \\
\hline Sub-total & 45.8 & 50.0 & 93.1 & 101.6 & 35.0 & 37.7 & 72.1 & 77.5 & 47.0 & 54.0 & 100.3 & 111.2 \\
\hline Soil & \multicolumn{2}{|c|}{207.0} & \multicolumn{2}{|c|}{214.8} & \multicolumn{2}{|c|}{239.1} & \multicolumn{2}{|c|}{241.7} & \multicolumn{2}{|c|}{231.7} & \multicolumn{2}{|c|}{238.4} \\
\hline Litter & \multicolumn{2}{|c|}{8.3} & \multicolumn{2}{|c|}{11.4} & \multicolumn{2}{|c|}{3.0} & & & & & & \\
\hline Woody debris & $\mathrm{N}$ & & & & & & & & & & & \\
\hline Total & 255.1 & 259.3 & 324.9 & 333.4 & 277.0 & 279.7 & 323.2 & 328.6 & 291.0 & 298.0 & 345.3 & 356.2 \\
\hline Flux $\left(\mathrm{Mg} \mathrm{C} \mathrm{ha}^{-1} \mathrm{a}^{-1}\right)$ & & & & & & & & & & & & \\
\hline Net biomass increment $\Delta B$ & & & & & & & & & & & & \\
\hline Litter production $L$ & & & & & & & & & & & & \\
\hline Dead root production $F$ & & & & & & & & & & & & \\
\hline Woody debris production $W$ & & & & & & & & & & & & \\
\hline Soil respiration $R_{\mathrm{s}}$ & & & & & & & & & & & & \\
\hline Heterotrophic respiration $R_{\mathrm{h}}$ & & & & & & & & & & & & \\
\hline Net primary production NPP & & & & & & & & & & & & \\
\hline Net ecosystem production NEP & & & & & & & & & & & & \\
\hline
\end{tabular}

(26\%), 0.69 (18\%) and $0.27(4 \%) \mathrm{Mg} \mathrm{C} \mathrm{ha}^{-1} \mathrm{a}^{-1}$. The largest change of $\mathrm{C}$ flux was in soil respiration. $R_{\mathrm{s}}$ in birch, oak, and pine forests increased by 2.65 (86\%), 0.65 (17\%), and $1.77(75 \%) \mathrm{Mg} \mathrm{C}^{-1} \mathrm{a}^{-1}$. Correspondingly, $R_{\mathrm{h}}$ increased by $2.42(87 \%), 0.61(17 \%)$, and $1.39(77 \%) \mathrm{Mg} \mathrm{C} \mathrm{ha}^{-1} \mathrm{a}^{-1}$, respectively (Table 2$)$.

\subsection{C budgets and changes in two decades}

Using the above accounting, we constructed the $\mathrm{C}$ budgets for these three temperate forests during 1992-1994 and 2011-2014 (Figure 1). The results indicated that these temperate forests were $\mathrm{C}$ sinks, but the strength of each $\mathrm{C}$ sink differed in each forest type. The highest rate of $\mathrm{C}$ sinks occurred in the pine plantation ecosystem $\left(3.53 \mathrm{Mg} \mathrm{C} \mathrm{ha}^{-1}\right.$ $\left.\mathrm{a}^{-1}\right)$, which was much higher than other two deciduous broadleaf forests $\left(0.12 \mathrm{Mg} \mathrm{C} \mathrm{ha}^{-1} \mathrm{a}^{-1}\right.$ for birch forest; and $0.43 \mathrm{Mg} \mathrm{C} \mathrm{ha}{ }^{-1} \mathrm{a}^{-1}$ for oak forest). Compared with 1992-1994, the strength of ecosystem $\mathrm{C}$ sinks obviously decreased in birch (1.33 $\left.\mathrm{Mg} \mathrm{C} \mathrm{ha}^{-1} \mathrm{a}^{-1}, 92 \%\right)$ and pine forests (1.12 $\left.\mathrm{Mg} \mathrm{C} \mathrm{ha}^{-1} \mathrm{a}^{-1}, 24 \%\right)$, whereas that increased slightly in the oak forest, from 0.35 to $0.43 \mathrm{Mg} \mathrm{C} \mathrm{ha}^{-1} \mathrm{a}^{-1}$.

\section{Discussion}

\subsection{C stocks and changes in two decades}

According to a previous study [27], the three forest stands in this study which were developed after the climax forests, had been repeatedly harvested without major soil disturbance. The ecosystem C stock was estimated as 323.2-333.4
$\mathrm{Mg} \mathrm{C} \mathrm{ha}{ }^{-1}$ for the two deciduous broadleaf forests and 345.3-356.2 $\mathrm{Mg} \mathrm{C} \mathrm{ha}^{-1}$ for the coniferous plantation, which were both higher than the average stock of temperate forests worldwide (189 $\mathrm{Mg} \mathrm{C} \mathrm{ha}^{-1}$ ) [28]. This suggests that the mountainous temperate forests in this study have sequestered relatively high amounts of carbon. Compared with the data of 1992-1994 [17], ecosystem C stocks increased by $16 \%-26 \%$ (excluding woody debris), of which living biomass contributed to a large share (Figure 1).

Even so, biomass contributes less than $30 \%$ of ecosystem $\mathrm{C}$ stock in this site, which is lower than that of other temperate forests. For instance, the contribution is $50 \%-70 \%$ in Mt. Changbai temperate primary forests across an elevational gradient [29] and 30\%-50\% in six temperate forests in Mt. Maoer [30]. The relatively lower contribution of biomass in ecosystem $\mathrm{C}$ stock results from higher $\mathrm{C}$ stock in soil organic matter at this study site. Soil organic $\mathrm{C}$ stock in the upper $1 \mathrm{~m}$ of soil was estimated at $214.8-241.7 \mathrm{Mg} \mathrm{C}$ $\mathrm{ha}^{-1}$, which is higher than the mean soil organic $\mathrm{C}$ stock in China's brown earths (97.1 $\mathrm{Mg} \mathrm{C} \mathrm{ha}^{-1}$ ) [31], and higher than the mean value of global temperate forests $(74.0 \mathrm{Mg} \mathrm{C}$ $\mathrm{ha}^{-1}$ ) [5]. Compared with the stocks in 1992-1994, soil organic $\mathrm{C}$ stocks increased slightly among the three forests (2.6-7.8 $\mathrm{Mg} \mathrm{C} \mathrm{ha}^{-1}$ ). Although these sectors sequester $\mathrm{C}$ at much lower rates than those of biomass, they should not be overlooked because of their importance in the process of $\mathrm{C}$ cycling [32]. Enhanced production of litter and dead roots could produce more potential inputs into soils and then result in additional soil $\mathrm{C}$ accumulation [33]. The relatively lower $\mathrm{C}$ accumulation rate observed here was probably caused by increased annual soil $\mathrm{C}$ efflux (Table 2).

In addition, $\mathrm{C}$ stocks in litter and woody debris account 


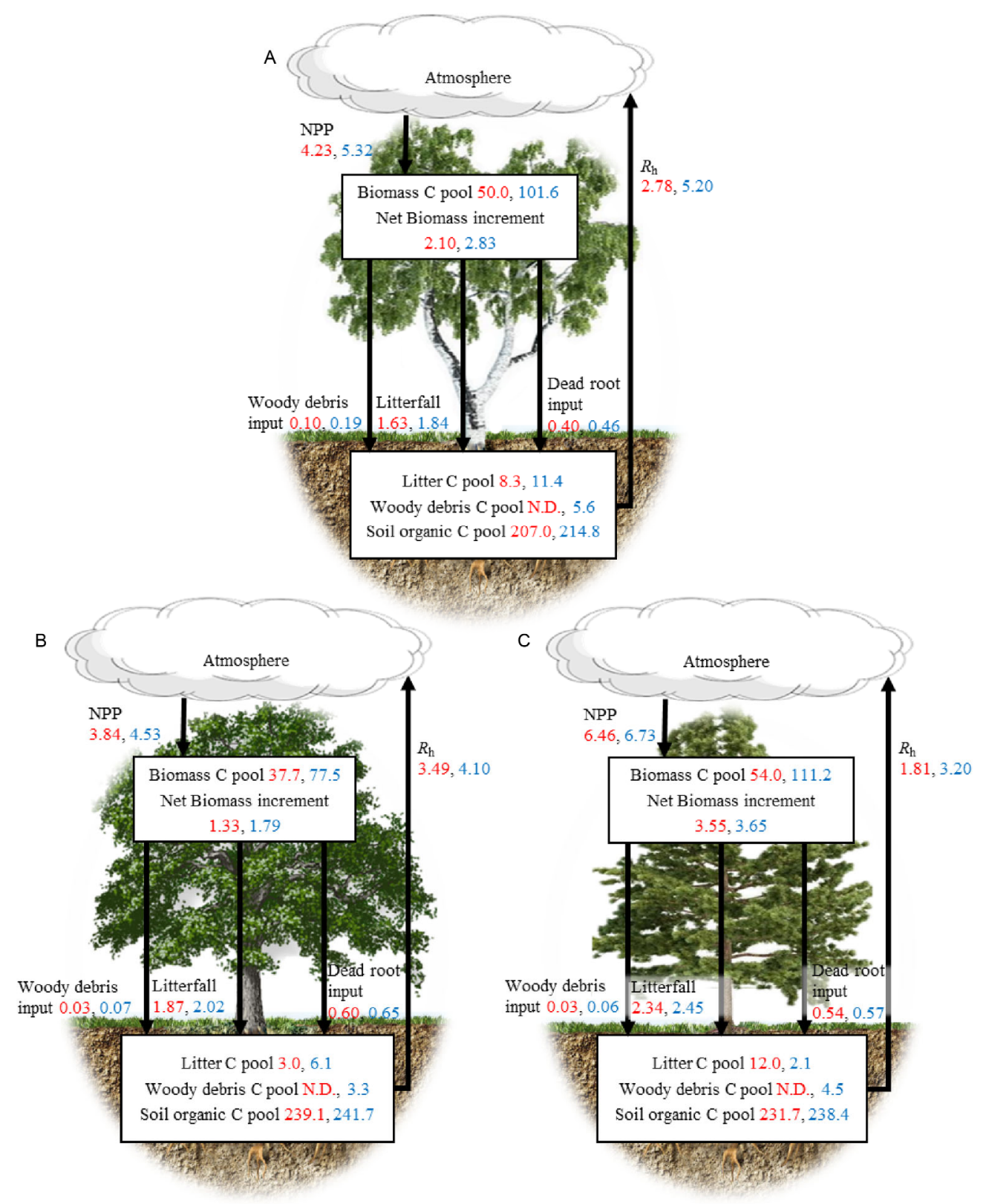

Figure 1 Carbon budgets of three temperate forest ecosystems and their changes in the recent two decades. A, Birch forest. B, Oak forest. C, Pine plantation. Red numbers are the $\mathrm{C}$ densities $\left(\mathrm{Mg} \mathrm{C} \mathrm{ha}^{-1}\right)$ or fluxes $\left(\mathrm{Mg} \mathrm{C} \mathrm{ha}^{-1} \mathrm{a}^{-1}\right)$ in 1992-1994 and blue numbers are the corresponding values in $2011-2014$. N.D., data are not available.

for only $2 \%-5 \%$ of the ecosystem $\mathrm{C}$ stocks, which is much lower than the mean ratio of global forests (13.5\%) [5]. Litter $\mathrm{C}$ stock in birch forest $\left(11.4 \mathrm{Mg} \mathrm{C} \mathrm{ha}^{-1}\right)$ was higher than those of $6.1 \mathrm{Mg} \mathrm{C} \mathrm{ha}^{-1}$ in oak and 2.1 $\mathrm{Mg} \mathrm{C} \mathrm{ha}^{-1}$ in pine forests. This probably occurred because the birch site is located at a relatively higher elevation with relatively low air temperatures (Table 1). Lower temperature-associated accumulation of litter was accompanied by a lower decomposition rate [33]. Compared with the stocks in 1992-1994, litter $\mathrm{C}$ stocks increased in the deciduous broadleaf forests but decreased in the pine plantation. In summary, the results show that temperate forest ecosystems in Mt. Dongling have functioned as a persistent $\mathrm{C}$ sink, sequestrating 44.1-60.3 $\mathrm{Mg} \mathrm{C} \mathrm{ha}^{-1}$.

\subsection{C flux and changes in two decades}

Net biomass increment of the three forests in this study were 1.8-3.7 $\mathrm{Mg} \mathrm{C} \mathrm{ha}^{-1} \mathrm{a}^{-1}$ during 2011-2014, which is much higher than the mean forest biomass $\mathrm{C}$ sink of China (0.5 $\mathrm{Mg} \mathrm{C} \mathrm{ha} \mathrm{a}^{-1}$ ) [10,17]. Two decades ago, forest productivity was relatively low in mountainous temperate 
forests in Beijing [17], e.g., lower NPP than that of other temperate forests at a similar latitude [34]. In the last two decades, rapid biomass accumulations occurred in the forests in this study, accompanied by increases in litter production, which led to an obvious increase in NPP (Figure 1). NPP of birth and oak forests was 5.32 and $4.53 \mathrm{Mg} \mathrm{C} \mathrm{ha}^{-1}$ $\mathrm{a}^{-1}$, respectively, which is comparable to that of birch and oak forests at a lower latitude in Japan $\left(6.5 \mathrm{Mg} \mathrm{C} \mathrm{ha}^{-1}\right.$ $\mathrm{a}^{-1}$ ) [35]. NPP in the pine plantation was estimated at 6.73 $\mathrm{Mg} \mathrm{Cha}{ }^{-1} \mathrm{a}^{-1}$, which is higher than that of other temperate pine forests at a similar latitude in the USA (5.2 $\mathrm{Mg} \mathrm{C} \mathrm{ha}^{-1}$ $\left.\mathrm{a}^{-1}\right)$ [36].

Meanwhile, annual soil respiration effluxes in birch, oak, and pine forests increased dramatically in the last two decades (17\%-86\%), at 5.74, 4.55, and $4.14 \mathrm{Mg} \mathrm{C} \mathrm{ha}^{-1} \mathrm{a}^{-1}$, respectively, during 2011-2014. Increased soil $\mathrm{C}$ releases might result from increased air temperature caused by climate change, increased biomass accumulation (Table 2), and the changes of substrate concentration of soil respiration [23]. Even so, the amount of these releases is still lower than that of other temperate broadleaf (8.1-11.9 $\mathrm{Mg} \mathrm{C} \mathrm{ha}^{-1}$ $\mathrm{a}^{-1}$ ) [37] and conifer forests (6.8 $\mathrm{Mg} \mathrm{C} \mathrm{ha}^{-1} \mathrm{a}^{-1}$ ) [38]. Lower soil respiration efflux is probably caused by the following two factors: (i) a low contribution of root biomass (only $20 \%$ ) to total biomass could lead to a low root respiration; (ii) low biomass of the understory and herb layers, and poor properties of water absorption and retention that may lead to low soil respiration rates, especially at the oak and pine forests [22,23]. Annual effluxes of $R_{\mathrm{h}}$ in the three stands in this study were estimated at $3.20-5.20 \mathrm{Mg} \mathrm{C} \mathrm{ha}^{-1} \mathrm{a}^{-1}$, which is comparable to other temperate forests in China [39].

The NEP is the net $\mathrm{C}$ balance between the ecosystem and the atmosphere, and is an evaluation criterion used to determine the presence of ecosystem C sink or source [40]. NEP in the three temperate forests are positive, but the strength of the sinks are decreasing. Birch and oak forests were nearly in balance in $\mathrm{CO}_{2}$ exchange with the atmosphere.

\subsection{Uncertainty analysis}

We constructed $\mathrm{C}$ budgets for three mountainous temperate forest ecosystems in Mt. Dongling, Beijing, and evaluated the changes of the $\mathrm{C}$ budgets during the last two decades (Figure 1). Additionally, we optimized the calculation in $\mathrm{C}$ budgets in 1992-1994 [17]. First, we measured C stock of the entire forest sector, adding the biomass $\mathrm{C}$ stock of herbs and woody debris into the calculation of the ecosystem $\mathrm{C}$ budget. Second, we estimated production of dead root and woody debris into NPP calculation, which improved the estimation of $\mathrm{C}$ inputs. Even so, the following three aspects may produce uncertainties related to $\mathrm{C}$ budget estimation.

(i) Although we added an estimate of dead root production into NPP estimation, other components of NPP were omitted, such as that of root exudates [40], losses of litter to decomposition before harvest, and the export of carbohydrates to symbionts [41]. These items of omission will lead to an underestimate of NPP.

(ii) Spatial heterogeneity of soil, including soil organic C and depth, may lead to uncertainties in the estimation of annual soil respiration efflux [42]. In addition, we did not measure the respiration rate in winter, which could result in an error in annual soil respiration efflux.

(iii) The ratio of $R_{\mathrm{h}}$ to $R_{\mathrm{s}}$ measured in 1994 and 1995 was used to estimate the 2011-2014 heterotrophic respiration, which would create uncertainties. In the last two decades, rapid biomass accumulations occurred in the temperate forests, and root biomass increased by $78 \%-135 \%$, which lead to increases in root respiration. Therefore, this ratio would cause an overestimate of $R_{\mathrm{h}}$ in 2011-2014. Moreover, substrate concentration, temperature, moisture and microbial composition and biomass in soil could be different between 1992-1994 and 2011-2014. All of these factors will induce uncertainties in our results.

\section{Conclusions}

Although the three temperate forests had different species composition and site conditions, they sequestered similar amounts of $\mathrm{C}$ in the last two decades. Ecosystem $\mathrm{C}$ stocks increased from $259.3-298.0 \mathrm{Mg} \mathrm{C}^{-1}$ to $328.6-356.2 \mathrm{Mg}$ $\mathrm{C} \mathrm{ha}^{-1}$ (not including woody debris). The biomass $\mathrm{C}$ sink rate was rapid (2.0-2.8 $\mathrm{Mg} \mathrm{C} \mathrm{ha}^{-1} \mathrm{a}^{-1}$ ), while soil organic $\mathrm{C}$ increased slightly $\left(0.1-0.4 \mathrm{Mg} \mathrm{C} \mathrm{ha}^{-1} \mathrm{a}^{-1}\right)$. In the recent three years (2011-2014), the NEP in the three temperate forests were positive, but the sink rates were decreasing compared with the results of 1992-1994. Both short- and long-term estimates demonstrated the three forest ecosystems functioned as persistent $\mathrm{C}$ sinks.

The authors declare that they have no conflict of interest.

This work was supported by National Natural Science Foundation of China (31321061, 31330012), and National Basic Research Program of China on Global Change (2014CB954001).

1 Kauppi PE, Mielikäinen K, Kuusela K. Biomass and carbon budget of European forests, 1971 to 1990. Science, 1992, 256: 70-74

2 Fang JY, Chen AP, Peng CH, Zhao S, Ci L. Changes in forest biomass carbon storage in China between 1949 and 1998. Science, 2001, 292: 2320-2322

3 Pacala SW, Hurtt GC, Baker D, Peylin P, Houghton RA, Birdsey RA, Heath L, Sundquist ET, Stallard RF, Ciais P, Moorcroft P, Caspersen JP, Shevliakova E, Moore B, Kohlmaier G, Holland E, Gloor M, Harmon ME, Fan SM, Sarmiento JL, Goodale CL, Schimel D, Field CB. Consistent land-and atmosphere-based U.S. carbon sink estimates. Science, 2001, 292: 2316-2320

4 Janssens IA, Freibauer A, Ciais P, Smith P, Nabuurs GJ, Folberth G, Schlamadinger B, Hutjes RW, Ceulemans R, Schulze ED, Valentini 
R, Dolman AJ. Europe's terrestrial biosphere absorbs 7 to $12 \%$ of European anthropogenic $\mathrm{CO}_{2}$ emissions. Science, 2003, 300: $1538-1542$

5 Pan YD, Birdsey RA, Fang JY, Houghton R, Kauppi PE, Kurz WA, Phillips OL, Shvidenko A, Lewis SL, Canadell JG, Ciais P, Jackson RB, Pacala SW, McGuire AD, Piao S, Rautiainen A, Sitch S, Hayes D. A large and persistent carbon sink in the world's forests. Science, 2011, 333: 988-993

6 Schimel DS, House JI, Hibbard KA, Bousquet P, Ciais P, Peylin P, Braswell BH, Apps MJ, Baker D, Bondeau A, Canadell J, Churkina G, Cramer W, Denning AS, Field CB, Friedlingstein P, Goodale C, Heimann M, Houghton RA, Melillo JM, Moore B 3rd, Murdiyarso D, Noble I, Pacala SW, Prentice IC, Raupach MR, Rayner PJ, Scholes RJ, Steffen WL, Wirth C. Recent patterns and mechanisms of carbon exchange by terrestrial ecosystems. Nature, 2001, 414: 169-172

7 Fang JY, Brown S, Tang Y, Nabuurs GJ, Wang XP, Shen HH. Overestimated biomass carbon pools of the northern mid-and high latitude forests. Clim Change, 2006, 74: 355-368

8 Fang JY, Guo ZD, Hu HF, Kato T, Muraoka H, Son Y. Forest biomass carbon sinks in East Asia, with special reference to the relative contributions of forest expansion and forest growth. Global Change Biol, 2014, 20: 2019-2030

9 Piao SL, Fang JY, Ciais P, Peylin P, Huang Y, Sitch S, Wang T. The carbon balance of terrestrial ecosystems in China. Nature, 2009, 458: 1009-1013

10 Guo ZD, Hu HF, Li P, Li NY, Fang JY. Spatio-temporal changes in biomass carbon sinks in China's forests from 1977 to 2008. Sci China Life Sci, 2013, 56: 661-671

11 DeLucia EH, Hamilton JG, Naidu SL, Thomas RB, Andrews JA, Finzi A, Lavine M, Matamala R, Mohan JE, Hendrey GR, Schlesinger WH. Net primary production of a forest ecosystem with experimental $\mathrm{CO}_{2}$ enrichment. Science, 1999, 284: 1177-1179

12 Monson RK, Lipson DL, Burns SP, Turnipseed AA, Delany AC, Williams MW, Schmidt SK. Winter forest soil respiration controlled by climate and microbial community composition. Nature, 2006, 439: 711-714

13 Brando PM, Nepstad DC, Davidson EA, Trumbore SE, Ray D, Camargo P. Drought effects on litterfall, wood production and belowground carbon cycling in an Amazon forest: results of a throughfall reduction experiment. Philos T R Soc B, 2008, 363: 1839-1848

14 Harmon ME, Bible K, Ryan MG, Shaw DC, Klopatek J, Li X. Production, respiration, and overall carbon balance in an old-growth Pseudotsuga-Tsuga forest ecosystem. Ecosystems, 2004, 7: 498-512

15 Phillips OL, Malhi Y, Higuchi N, Laurance WF, Nunez PV, Vasquez RM, Laurance SG, Ferreira LV, Stern M, Brown S, Grace J. Changes in the carbon balance of tropical forests: evidence from long-term plots. Science, 1998, 282: 439-442

16 Chen DX, Li YD, Liu HP, Xu H, Xiao W, Luo T, Zhou Z, Lin M. Biomass and carbon dynamics of a tropical mountain rain forest in China. Sci China Life Sci, 2010, 53: 798-810

17 Fang JY, Liu GH, Zhu B, Wang XK, Liu SH. Carbon budgets of three temperate forest ecosystems in Dongling Mt., Beijing, China. Sci China Earth Sci, 2007, 50: 92-101

18 Hu X, Zhu J, Wang C, Zheng T, Wu Q, Yao H, Fang JY. Impacts of fire severity and post-fire reforestation on carbon pools in boreal larch forests in Northeast China. J Plant Ecol, 2015, doi: 10.1093/ jpe/rtv036

19 Wofsy SC, Goulden ML, Munger JW, Fan SM, Bakwin PS, Daube BC, Bassow SL, Bazzaz FA. Net exchange of $\mathrm{CO}_{2}$ in a mid-latitude forest. Science, 1993, 260: 1314-1317

20 Lee X. On micrometeorological observations of surface-air exchange over tall vegetation. Agr Forest Meteorol, 1998, 91: 39-49
21 Zhang XS. The Vegetation Map of China $(1: 1,000,000)$ (in Chinese). Beijing: Geology Press, 2007

22 Liu SH, Fang JY, Makoto K. Soil respiration of mountainous temperate forests in Beijing, China (in Chinese). Acta Phytoecol Sin, 1998, 22: 119-126

23 Yao H, Hu XY, Zhu JL, Zhu JX, Ji CJ, Fang JY. Soil respiration and the 20-year change in three temperate forests in Mt. Dongling, Beijing (in Chinese). Acta Phytoecol Sin, 2015, 39: 849-856

24 Leith H, Whittaker RH. Primary Production of the Biosphere: Ecological Studies. Berlin: Springer, 1975

25 Nadelhoffer KJ, Raich JW. Fine root production estimates and belowground carbon allocation in forest ecosystems. Ecology, 1992, 73: 1139-1147

26 Lu RK. Soil and Agro-Chemical Analytical Methods (in Chinese). Beijing: China Agricultural Science and Technology Press, 2000

27 Wu XP, Wang ZH. Community structures and species composition of oak forests in mountainous area of Beijing (in Chinese). Chin Biodivers, 2004, 12: 155-163

28 Pregitzer KS, Euskirchen ES. Carbon cycling and storage in world forests: biome patterns related to forest age. Global Change Biol, 2004, 10: 2052-2077

29 Zhu B, Wang X, Fang J, Piao S, Shen H, Zhao S, Peng C. Altitudinal changes in carbon storage of temperate forests on Mt Changbai, Northeast China. J Plant Res, 2010, 123: 439-452

30 Zhang QZ, Wang CK. Carbon density and distribution of six Chinese temperate forests. Sci China Life Sci, 2010, 53: 831-840

$31 \mathrm{Wu} \mathrm{H}$, Guo Z, Peng C. Distribution and storage of soil organic carbon in China. Global Biogeochem Cy, 2003, 17, 1048

32 Zhou G, Liu S, Li Z, Zhang D, Tang X, Zhou C, Yan J, Mo J. Old-growth forests can accumulate carbon in soils. Science, 2006, 314: 1417-1417

33 Davidson EA, Janssens IA. Temperature sensitivity of soil carbon decomposition and feedbacks to climate change. Nature, 2006, 440: 165-173

34 Hamilton JG, DeLucia EH, George K, Naidu SL, Finzi AC, Schlesinger WH. Forest carbon balance under elevated $\mathrm{CO}_{2}$. Oecologia, 2002, 131: 250-260

35 Ohtsuka T, Mo W, Satomura T, Inatomi M, Koizumi H. Biometric based carbon flux measurements and net ecosystem production (NEP) in a temperate deciduous broad-leaved forest beneath a flux tower. Ecosystems, 2007, 10: 324-334

36 Arthur MA, Fahey TJ. Biomass and nutrients in an Engelmann spruce-subalpine fir forest in north central Colorado: pools, annual production, and internal cycling. Can J Forest Res, 1992, 22: 315-325

37 Bolstad PV, Davis KJ, Martin J, Cook BD, Wang W. Component and whole-system respiration fluxes in northern deciduous forests. Tree Physiol, 2004, 24: 493-504

38 Law BE, Ryan MG, Anthoni PM. Seasonal and annual respiration of a ponderosa pine ecosystem. Global Change Biol, 1999, 5: 169-182

39 Wang CK, Yang JY, Zhang QZ. Soil respiration in six temperate forests in China. Global Change Biol, 2006, 12: 2103-2114

40 Schlesinger WH. Biogeochemistry: an Analysis of Global Change. 2nd ed. New York: Academic Press, 1997

41 Clark DA, Brown S, Kicklighter DW, Chambers JQ, Thomlinson JR, Ni J. Measuring net primary production in forests: concepts and field methods. Ecol Appl, 2001, 11: 356-370

42 Scott-Denton LE, Rosenstiel TN, Monson RK. Differential controls by climate and substrate over the heterotrophic and rhizospheric components of soil respiration. Global Change Biol, 2006, 12: 205-216

Open Access This article is distributed under the terms of the Creative Commons Attribution License which permits any use, distribution, and reproduction in any medium, provided the original author(s) and source are credited. 